\title{
The Role of Kaolin Particles in the Performance of a Carbamate-Based Biocide for Water Bacterial Control
}

\author{
Maria Olivia Pereira, Maria João Vieira, Luis F. Melo
}

\begin{abstract}
The influence of kaolin particles on the activity of Pseudomonas fluorescens and on the efficacy of a carbamate-based biocide was investigated. The results indicated that kaolin particles stimulated the activity of the bacteria for all buffered $\mathrm{pH}$ values studied (5, 7 and 9); this effect being more evident for the tests carried out at $\mathrm{pH} 5$ and 9. The presence of the clay in P. fluorescens suspensions decreased the efficiency of disinfection of the carbamate. The results also showed that kaolin was very effective in removing carbamate from the culture media. Therefore, the biocide concentration in the solution decreased, and consequently its availability to the bacteria was reduced. The results could be explained by the interaction between kaolin particles and carbamate and by the changes in the configuration of kaolin aggregates, depending on the $\mathrm{pH}$ value. Water Environ. Res., 74, 7 (2002).
\end{abstract}

KEYWORDS: biocide, clay particles, respiratory activity, adsorption, Pseudomonas fluorescens.

\section{Introduction}

In a large number of industries, water is obtained from rivers and lakes because of the plentiful supply at low cost. The use of this source of water introduces not only microorganisms in the system, but also nonliving particulate matter that commonly includes sand, silt, and clays, inducing the buildup of mixed biological and inorganic deposits. The mechanisms on which particles and microorganisms interact should be investigated in more detail to understand the behavior of these "mixed biofilms."

Clay minerals have a high surface area and are ionogenic, therefore attracting substrates, retaining water molecules (Burns, 1989), and playing, in this way, an important role in microbial activity. Kaolinite is a $1: 1(\mathrm{Si} / \mathrm{Al})$ clay mineral, an aluminum silicate, that occurs in the form of thin, roughly hexagonal platelets. Under natural conditions, kaolinite particles carry a negative charge distributed over the basal surfaces. Under acidic conditions, the edges of the platelets tend to bind hydrogen ions, assuming a positive charge; this causes electrostatic attraction between edges and faces with the formation of a highly expanded configuration sometimes called a "card-house" structure. Under alkaline conditions, the edges become neutral or positively charged and the clay particles defloculate. At high electrolyte concentration, the repulsive electrostatic forces between particles are reduced, and dense "card-pack" aggregates are formed by particles that adhere to one another along their basal surfaces (Michaels and Bolger, 1962).

Interactions between inorganic particles and microorganisms may play an important role in the bacterial attachment processes, as well as in the microbial activity. The presence of certain clays, as kaolinite, in aqueous systems modifies the environment in which the microorganisms live (indirect effects), thus affecting the growth and metabolic activities of microbes. The effects that involve surface interaction (e.g., adhesion) between clays and microorganisms are considered direct effects and relatively little is known about them. Adsorption and binding of organic compounds to clay minerals are also discussed as direct effects because of the similarity of the mechanisms involved (Stotzky, 1986).

The purpose of this work was to study the interaction of kaolin particles (basically composed of kaolin) with suspended cultures of Pseudomonas fluorescens, as well as with a carbamate-based biocide used against those cultures, at several $\mathrm{pH}$ levels and for different contact times. The results of this study can also be useful to interpret the effects of biocides in biofilms containing clay particles.

\section{Methods and Materials}

Microorganism and Cell Growth. A continuous culture of the Gram-negative aerobic bacteria $P$. fluorescens (CECT 378 [Catalogue of Strains, 4th Ed., 1998, Universitat de Valência, Spain]) was grown at $27{ }^{\circ} \mathrm{C}$ in a 3-L glass fermenter, suitably aerated, and magnetically agitated. The fermenter was continuously fed with 10 $\mathrm{mL} / \mathrm{h}$ of a sterile nutrient solution composed of $5 \mathrm{~g}$ glucose $/ \mathrm{L}$, $2.5 \mathrm{~g}$ peptone/L, and $1.25 \mathrm{~g}$ yeast extract/L, in phosphate buffer at $\mathrm{pH} 7$ (0.2 $\mathrm{M}$ dibasic sodium orthophosphate, $\mathrm{Na}_{2} \mathrm{HPO}_{4}$, and $0.2 \mathrm{M}$ monobasic sodium orthophosphate, $\mathrm{NaH}_{2} \mathrm{PO}_{4}$ ).

Biocide. A nonoxidising biocide solution (NALCON 7614, NALCO, Lisbon, Portugal) composed of sodium dimethyl dithiocarbamate $(15 \% \mathrm{w} / \mathrm{v})$ and disodium ethylene bisthiocarbamate $(15 \% \mathrm{w} / \mathrm{v})$ in water, herewith referred to as "carbamate" for simplicity, was tested. The active constituent of carbamate, an organosulfur, works as an antimetabolite agent, interrupting the metabolic action of microorganisms and attacking the cell membrane.

Clay Particles. Kaolin particles (BA220C, Companhia AngloPortuguesa de Caulinos de Viana, Viana do Castelo, Portugal), diameter between 5 and $10 \mu \mathrm{m}$, were used to investigate the effect of abiotic particles on the respiratory activity of suspended cultures of the bacteria, with and without the addition of biocide. In all experiments, the effective concentration of kaolin was $300 \mathrm{mg} / \mathrm{L}$.

Analytical Methods. Periodically, a suitable amount of $P$. fluorescens culture was removed from the fermenter, under sterile conditions, centrifuged at $5000 \mathrm{r} / \mathrm{min}$ for 10 minutes, and washed three times with phosphate buffer. The pellets thus obtained were resuspended in one of the following buffers, according to the $\mathrm{pH}$ value in each assay: phosphate buffer, $\mathrm{pH} 7$ and 9 and acetate buffer, pH 5. A known amount of kaolin was added to this 
suspended culture. The bacterial culture obtained was then distributed in several sterilized glass flasks and put in an orbital stirrer $\left(120 \mathrm{r} / \mathrm{min}\right.$ at $\left.27^{\circ} \mathrm{C}\right)$. After approximately 30 minutes (for adaptation of the bacteria to the new $\mathrm{pH}$ established) a known amount of biocide was added to each flask in a way to obtain different concentrations of the chemical $(100,200$, and $300 \mathrm{mg} / \mathrm{L})$. One of the flasks was used as a control, without biocide addition.

At known time intervals (immediately after biocide addition, and after 1, 3, and 7 hours) samples of each flask were transferred to a respiration chamber to evaluate their cellular activity (through oxygen consumption).

Oxygen Uptake Rates. The respiratory activity of the samples was evaluated by measuring oxygen uptake rates in a biological oxygen monitor (BOM) in short-term assays. The assays were performed in a Yellow Springs Instruments (Yellow Springs Instrument Co., Inc., Yellow Springs, Ohio) BOM (Model 53) according to the procedure described by Nogueira et al. (1998). Before each respirometric assay, the samples of the bacterial cultures (with and without kaolin particles) were washed three times with saline solution $(0.85 \%$ sodium chloride), resuspended in $10 \mathrm{~mL}$ of the appropriate buffer solution, and placed in the temperature-controlled vessel of the BOM. In the present case, the buffers were the ones referred to previously, and the temperature in the measuring chamber was $27{ }^{\circ} \mathrm{C}$. The vessel contains a dissolved oxygen (DO) probe connected to a DO meter. Once inside the vessel, the bacterial cultures were aerated for 30 minutes to ensure oxygen saturation. The vessel was closed and the decrease of the oxygen concentration was monitored over time. The initial linear decrease observed corresponds to the endogenous respiration rate. To determine the oxygen uptake due to substrate oxidation, a small volume $(50 \mu \mathrm{L})$ of a glucose solution $(100$ $\mathrm{mg} / \mathrm{L}$ ) was injected to each vessel. The slope of the initial linear decrease in the DO concentration, after glucose injection, corresponds to the total respiration rate. The difference between the two respiration rates gives the oxygen uptake rate due to the glucose oxidation. All of the respirometric tests were carried out twice.

Biocide Adsorption. The possibility of carbamate adsorption to clay particles was investigated by UV absorbency at a wavelength of $280 \mathrm{~nm}$ (the maximum peak of carbamate UV absorbency). The tests were performed twice, in batch assays at $25^{\circ} \mathrm{C}$, by putting carbamate solutions with different concentrations $(1,5,10,15,20$, $50,100,200$, and $300 \mathrm{mg} / \mathrm{L}$ ) in contact with $300 \mathrm{mg} / \mathrm{L}$ of kaolin. The flasks were placed in an orbital stirrer $\left(150 \mathrm{r} / \mathrm{min}\right.$ at $\left.25^{\circ} \mathrm{C}\right)$ and at known time intervals (immediately after the addition of kaolin and after 1, 3, 7, 24, 48, 96, and 144 hours). A sample was removed from each flask, filtered through a $0.2-\mu \mathrm{m}$ membrane filter, and its carbamate content evaluated by UV absorbency. A $300 \mathrm{mg} / \mathrm{L}$ kaolin suspension (filtrated after each time interval) without carbamate was used as a blank assay in all of the UV measurements.

To obtain more details on the interaction between kaolin particles and the biocide, several UV absorbency scanning runs were performed in a UV-visible spectrophotometer (model 7850, JASCO Inc., Easton, Maryland) with samples of a carbamate solution $(10 \mathrm{mg} / \mathrm{L})$, a kaolin suspension $(300 \mathrm{mg} / \mathrm{L})$, and a carbamate $(10 \mathrm{mg} / \mathrm{L})$ plus kaolin $(300 \mathrm{mg} / \mathrm{L})$ suspension (after 48 hours of contact) in the wavelength range of 190 to $320 \mathrm{~nm}$. A similar procedure was applied to the same samples after filtration (0.2- $\mu \mathrm{m}$ membrane filter).

\section{Results}

To evaluate the effect of the kaolin particles $(300 \mathrm{mg} / \mathrm{L})$ on the respiratory activity of the $P$. fluorescens suspended cultures, several tests were carried out at different $\mathrm{pH}$ values and for different contact times of the cultures with the clay particles. The results obtained are given in Figure 1, which shows that the microbial activity due to glucose oxidation was enhanced by adding clay particles, for all $\mathrm{pH}$ values. The results were statistically tested by using the Student's $t$ test distribution to assess whether the differences between the experimental values obtained at each $\mathrm{pH}$, with and without kaolin particles, could be considered significant. The effect of kaolin on respiratory activity was found to be statistically significant because the confidence level for 3 degrees of freedom was greater than $95 \%$ for $\mathrm{pH} 5$ and 9 and more than $90 \%$ for $\mathrm{pH} 7$.

Figure 1 also shows that the percentage increase in the bacterial activity when kaolin is added is considerably different for the various $\mathrm{pH}$ values. It becomes clear, from Figure 1, that the major overall increase was attained for the buffered assays at $\mathrm{pH} 5$ (27 to $43 \%$ ); whereas the assays performed at $\mathrm{pH} 9$ (19 to 39\%) and 7 (11 to $13 \%$ ) showed decreasing results. It must be stressed that the optimum $\mathrm{pH}$ for the growth of $P$. fluorescens is 7 (Oliveira et al., 1994, and Pinheiro et al., 1988). It seems that the kaolin effect is more evident when the growth conditions deviate from the optimum values.

Figure 1 also shows that the greatest amount of bacterial activities was always obtained in the assays carried out at $\mathrm{pH} 7$, and the lowest activities were obtained for $\mathrm{pH}$. This fact occurs in both types of assays, with and without kaolin.

Some authors (Burns, 1989; Castellar et al., 1998; and Stotzky, 1986) assumed that the stimulation of the microbial activity achieved through the addition of inorganic particles is due, among other factors, to their ability to maintain the $\mathrm{pH}$ of the media within suitable values. Therefore, to verify whether the $\mathrm{pH}$ of each buffered assay was modified by the presence of $300 \mathrm{mg} / \mathrm{L}$ of kaolin, the $\mathrm{pH}$ of the suspended cultures was monitored as a function of time and no significant changes were observed. Maintenance of the $\mathrm{pH}$ of the media to approximately the same values as those of the buffered media, as a consequence of the strength of the buffer, indicates that the effect of the kaolin as a $\mathrm{pH}$ regulator does not exist in buffered solutions.

During these assays, kaolin particles of the various $P$. fluorescens and kaolin suspensions were removed for examination by scanning electron microscopy. Figure 2 emphasizes the "cardpack" configuration of the kaolin particles that occurs for alkaline $\mathrm{pH}$ values. It is interesting to observe some bacteria attached to kaolin, some of them being placed (or sheltered) between kaolin platelets.

The role of kaolin on the bacterial activity was also studied in the presence of the biocide. Figures 3, 4, and 5 show the results from the respirometric assays of suspended cultures of $P$. fluorescens with $300 \mathrm{mg} / \mathrm{L}$ of kaolin, in the presence of different concentrations of carbamate, for different contact times, and for different $\mathrm{pH}$ values.

The results demonstrate that the presence of the carbamatebased biocide causes, for the $\mathrm{pH}$ values 7 and 9 , a reduction in the activity of $P$. fluorescens; this reduction being more evident when the $\mathrm{pH}$ of the bacterial culture is 9 (Figure 4). When the $\mathrm{pH}$ is 7 (Figure 3), the optimum $\mathrm{pH}$ for this strain, the presence of the carbamate causes a smaller decrease, although it becomes more pronounced for longer biocide contact times ( 3 hours and 7 hours). 


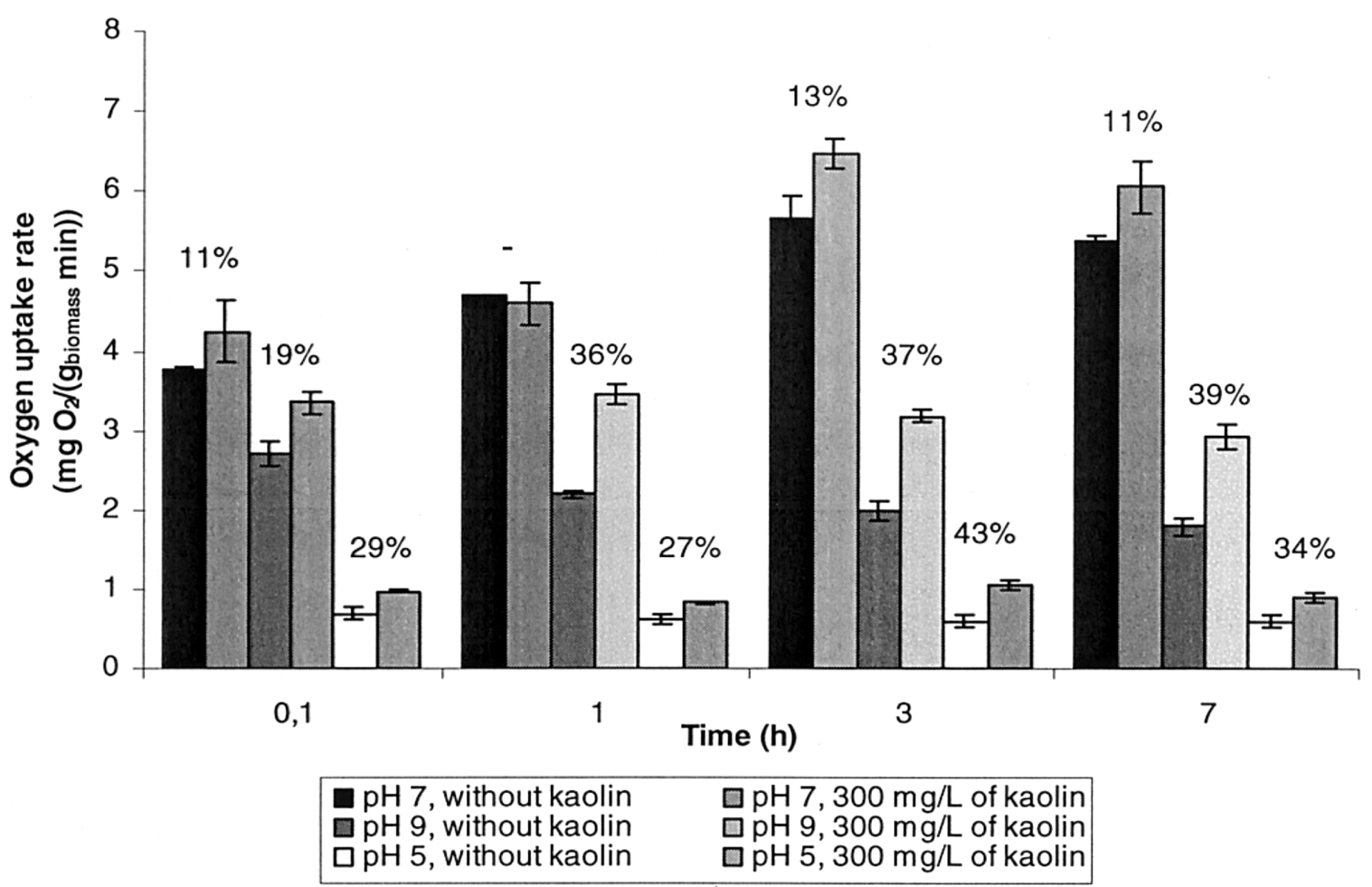

Figure 1-Oxygen uptake rates as a result of glucose consumption by suspended cultures of $P$. fluorescens as a function of time for several $\mathrm{pH}$ values (the bars display the standard deviation of the mean value). The percentage values represent the change in the bacterial activity caused by the presence of kaolin particles.

However, in the assays performed at $\mathrm{pH} 5$ (Figure 5), there was an unexpected increase in the $P$. fluorescens activity with the addition of biocide, when the bacterial suspension was treated with 100 and $200 \mathrm{mg} / \mathrm{L}$ of biocide. Only for the higher carbamate concentration of $300 \mathrm{mg} / \mathrm{L}$ was a slight reduction in the bacterial activity observed.

Some authors (Amin and Jayson, 1996, and Huang and Yang,
1995) report that clays have the potential for removing certain organic substances from water. To investigate whether kaolin particles can remove carbamate molecules, several carbamate solutions (with different initial concentrations) were placed in contact with $300 \mathrm{mg} / \mathrm{L}$ of kaolin, and the carbamate content was followed by UV absorbency during a period of 144 hours. The results given in Table 1 demonstrate that kaolin was very effective

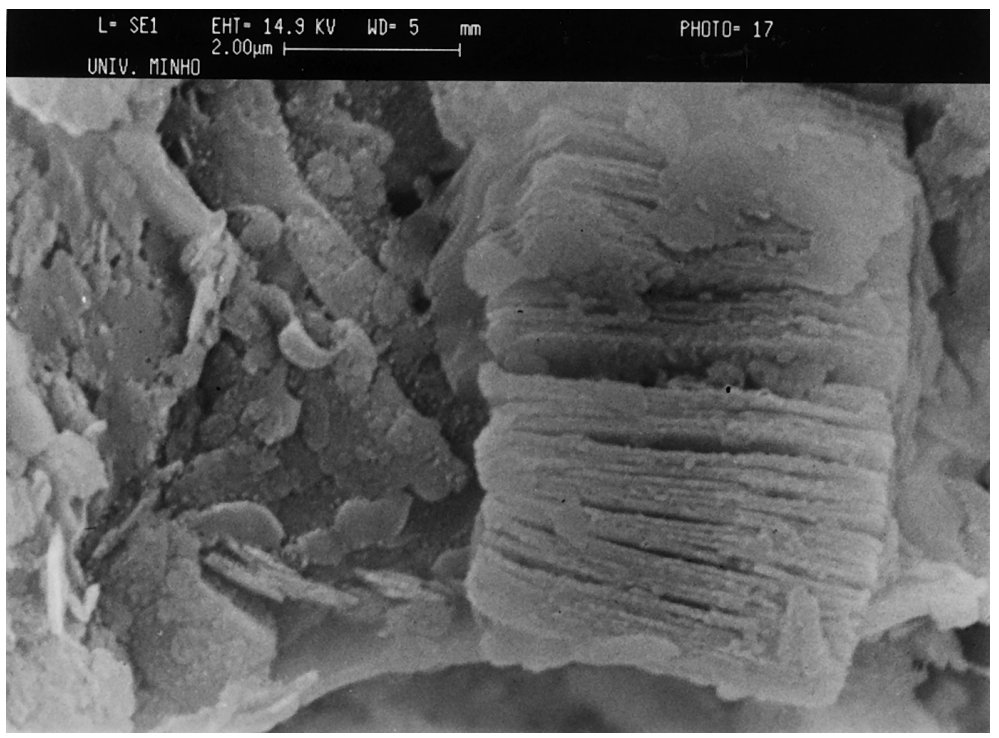

Figure 2-SEM micrograph $(7400 \times)$ of a kaolin and $\boldsymbol{P}$. fluorescens suspension, pH 9 phosphate buffer. 


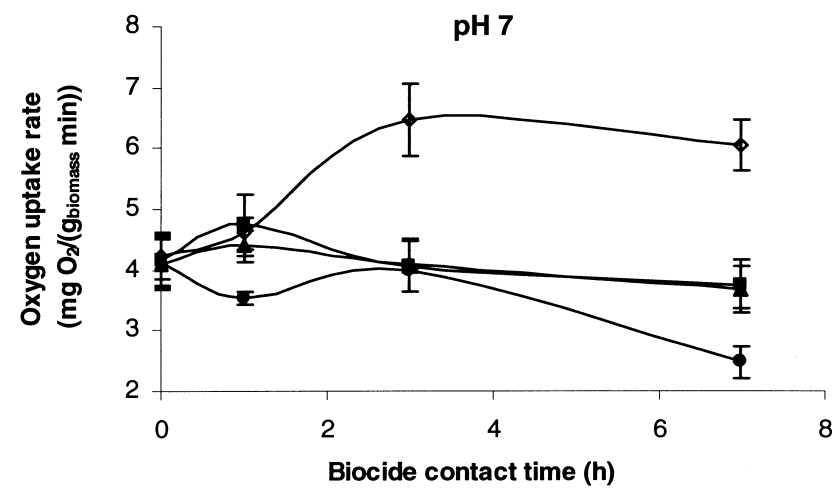

$\multimap 0 \mathrm{mg} / \mathrm{L} \rightarrow-100 \mathrm{mg} / \mathrm{L} \multimap-200 \mathrm{mg} / \mathrm{L} \multimap-300 \mathrm{mg} / \mathrm{L}$

Figure 3-Oxygen uptake rates of suspended cultures of P. fluorescens, $\mathrm{pH} 7$ phosphate buffer, with $300 \mathrm{mg} / \mathrm{L}$ of kaolin, when treated with different concentrations of carbamate, as a function of time; the bars display the standard deviation of the mean value.

in removing carbamate from solution. For lower biocide concentrations ( 1 to $17.9 \mathrm{mg} / \mathrm{L}$ ), kaolin achieved a $100 \%$ removal of biocide just after 1 hour contact. For higher carbamate concentrations (20.8 to $52.1 \mathrm{mg} / \mathrm{L})$, complete removal was reached after a longer time. At the highest concentrations ( 98.5 to $360 \mathrm{mg} / \mathrm{L}$ ), the amount of carbamate in the bulk liquid continuously decreased with time, and the efficiency of removal also decreased.

To verify whether the interaction between kaolin particles and the biocide is based on physical or chemical adsorption, filtered and unfiltered samples of carbamate solution $(10 \mathrm{mg} / \mathrm{L})$, kaolin (300 mg/L), and kaolin $(10 \mathrm{mg} / \mathrm{L})$ and carbamate $(300 \mathrm{mg} / \mathrm{L})$ suspensions were analyzed by performing UV scanning runs. The UV scanning curves of the filtered samples (Figure 6) show that, once again, carbamate disappears from the liquid phase of the kaolin and carbamate suspension, because its scanning curve is clearly below the one obtained when no kaolin was added. Figure

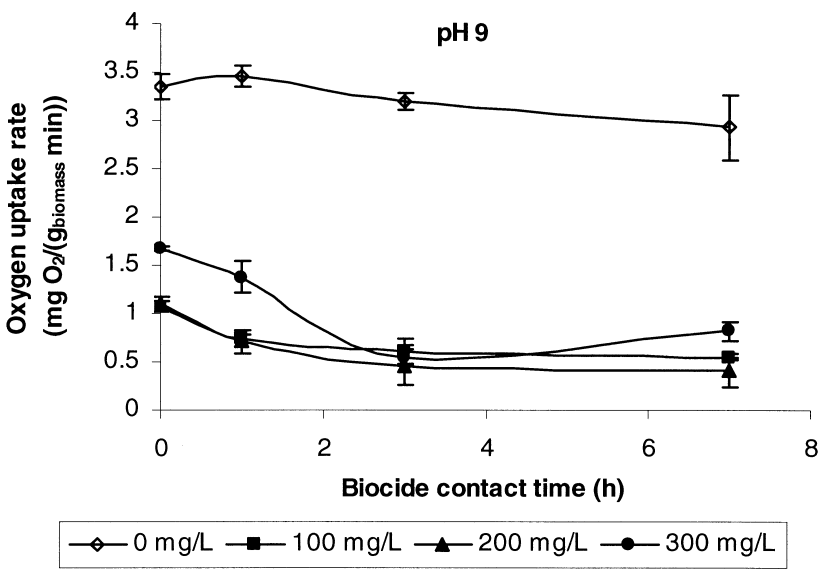

Figure 4-Oxygen uptake rates of suspended cultures of $P$. fluorescens, pH 9 phosphate buffer, with $300 \mathrm{mg} / \mathrm{L}$ of kaolin, when treated with different concentrations of carbamate, as a function of time; the bars display the standard deviation of the mean value.

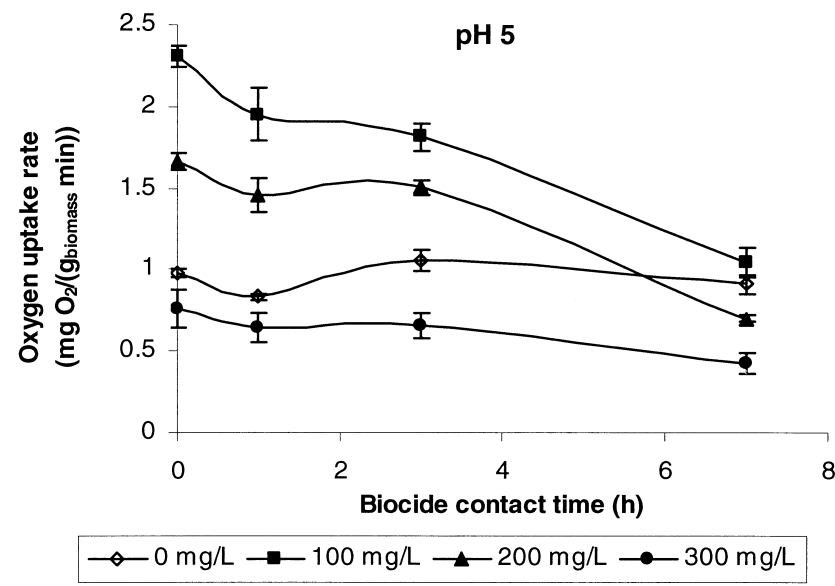

Figure 5-Oxygen uptake rates of suspended cultures of $P$. fluorescens, pH 5 acetate buffer, with $300 \mathrm{mg} / \mathrm{L}$ of kaolin, when treated with different concentrations of carbamate, as a function of time; the bars display the standard deviation of the mean value.

7 displays the UV scanning curves obtained with the unfiltered samples. As can be seen, the kaolin and carbamate suspension exhibits a much greater absorbency than the one obtained with the filtered sample, indicating that a structural modification probably occurs because of a chemical link of carbamate with kaolin surfaces.

\section{Discussion}

In general, clay particles, such as kaolin, have the ability to enhance bacterial activity (here measured by oxygen consumption). This enhancement has been explained by the clay's ability to adsorb the products of bacterial metabolism, maintaining a constant hydrogen ion concentration (Burns, 1989) and, therefore, keeping the $\mathrm{pH}$ of the media suitable for bacterial growth.

In the present study, the increase in $P$. fluorescens respiratory activity because of the presence of kaolin particles, noticed in Figure 1 (exogenous respiration), cannot be discussed in these terms because the culture media used for bacteria cultivation were initially buffered. It was experimentally confirmed that the $\mathrm{pH}$ did not change significantly with time. This means that, in these assays, the capacity of kaolin to act as a $\mathrm{pH}$ regulator is not explicit. Therefore, the increase in the bacterial activity obtained in almost all assays must be attributed to other mechanisms.

According to Stotzky (1986), some clay species contribute to the increase in the respiration rate of most bacteria, even when the culture media are initially adjusted to or buffered at $\mathrm{pH}$ 7. This indicates that some additional mechanism (other than the $\mathrm{pH}$ effect) is involved in the stimulation of the respiratory activity by clay minerals. Such additional mechanisms were not well defined, although some hypotheses have been suggested but not verified (Srinivasan et al., 1995). Furthermore, there is not yet a sound explanation for the smaller effect of kaolin in the case of $\mathrm{pH} \mathrm{7,} \mathrm{as}$ compared with the assays at $\mathrm{pH} 5$ and 9.

Nevertheless, the well-known changes in the spatial configuration of kaolin aggregates with $\mathrm{pH}$ (Michaels and Bolger, 1962) suggest an additional explanation. The kaolin "house of cards" configuration observed for acid $\mathrm{pH}$ values represents an expanded system that confers a larger available surface area for bacterial 
Table 1-Reduction in carbamate concentration in presence of $300 \mathrm{mg} / \mathrm{L}$ of kaolin as a function of time.

\begin{tabular}{|c|c|c|c|c|c|c|c|c|c|}
\hline \multirow{2}{*}{$\begin{array}{l}\text { Time } \\
\text { (h) } \\
* b\end{array}$} & \multicolumn{9}{|c|}{ Carbamate concentration $(\mathrm{mg} / \mathrm{L})^{a}$} \\
\hline & $1( \pm 7.2)$ & $5.6( \pm 1.7)$ & $9.8( \pm 0.2)$ & $17.9( \pm 0.6)$ & $20.8( \pm 0.5)$ & $52.1( \pm 1.3)$ & $98.5( \pm 1.1)$ & $276( \pm 11.7)$ & $360( \pm 18.2)$ \\
\hline 1 & 0 & 0 & 0 & 0 & $7.2( \pm 1.4)$ & $43.6( \pm 3.9)$ & $94.6( \pm 2.0)$ & $257.6( \pm 10.3)$ & $329.7( \pm 15.3)$ \\
\hline 3 & 0 & 0 & 0 & 0 & 0 & $42.0( \pm 5.8)$ & $93.5( \pm 2.1)$ & $257.9( \pm 10.3)$ & $323.7( \pm 11.4)$ \\
\hline 7 & 0 & 0 & 0 & 0 & 0 & $38.8( \pm 0.7)$ & $80.7( \pm 3.0)$ & $236.1( \pm 8.6)$ & $320.0( \pm 15.0)$ \\
\hline 96 & 0 & 0 & 0 & 0 & 0 & $4.6( \pm 0.1)$ & $23.3( \pm 0.7)$ & $129.4( \pm 0.4)$ & $196.2( \pm 5.2)$ \\
\hline 144 & 0 & 0 & 0 & 0 & 0 & 0 & $12.5( \pm 0.2)$ & $89.9( \pm 2.6)$ & $134.7( \pm 0.8)$ \\
\hline
\end{tabular}

a Standard deviation from the mean value given in parentheses; $n=2$.

${ }^{\mathrm{b}}$ Carbamate concentration before kaolin addition.

${ }^{\mathrm{C}}$ Carbamate concentration immediately after kaolin addition.

interactions, as well as for the adsorption of $\mathrm{H}^{+}$ions (produced during glucose uptake) on the particles. This expanded system maintains a favorable microenvironment for bacterial growth within the kaolin flocs. Kaolin particles can release ions (such as $\mathrm{Ca}^{2+}, \mathrm{Mg}^{2+}, \mathrm{S}^{-}$, and $\mathrm{Al}^{3+}$ ) from its own lattice to the medium (Stotzky, 1986) which are beneficial to the bacterial metabolism. Vieira et al. (2001) related that the ions released from the clay are not inhibitory for the bacterial cells. These facts may explain the relatively greater increase in the overall bacterial activity obtained in the assays performed at $\mathrm{pH} 5$ (the more adverse $\mathrm{pH}$ for bacterial growth in this work) (Figure 1).

In the "pack of cards" geometry, the particles are stacked one over another (Figure 2), hence drastically reducing the surface area available for the interactions with bacteria and solution. This fact contributes to the decreased microbial activity at $\mathrm{pH} 9$ as compared with that at $\mathrm{pH} 5$. At the greater $\mathrm{pH}$, the creation of favorable places for the bacteria between kaolin plates is hindered since bacteria have a limited area for attachment. The ion exchange

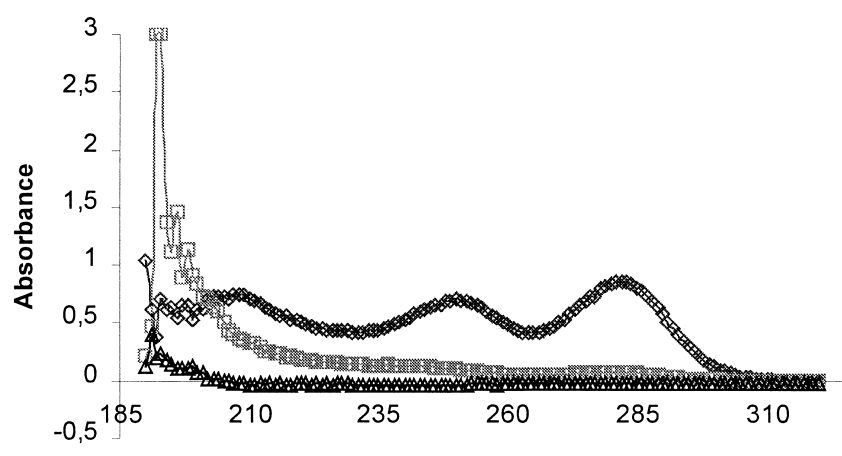

$\lambda(\mathrm{nm})$

Figure 6-UV absorbency scanning curves of filtrated samples of the carbamate solution, the kaolin suspension, and the kaolin and carbamate suspension $(\lambda=$ wavelength).

capacity is also limited in this case because of the reduction in the exposed area.

The decrease in bacterial activity when the microbial cultures were treated with carbamate was expected. This decrease is due to the intrinsic toxic activity of the biocide, although carbamate is known as a mild biocide due to its relatively low toxicity. Nevertheless, the low biocide efficacy may also be attributed to the fact that carbamate molecules could be adsorbed onto the kaolin surfaces and thus be removed from the solution (Table 1). According to Burns (1975), the adsorption of pesticides on clays influences their availability to microorganisms. Thus, in the present case, it was thought that once adsorbed, the carbamate-based biocide could partially or totally lose its toxic activity. The UV absorbency scanning experiments carried out to test this last hypothesis (Figures 6 and 7) suggest that a chemical modification occurs when carbamate and kaolin particles are placed in contact. It can also be said that the new compound remains adsorbed in the clay surfaces because the scanning curve, when kaolin and carbamate are present (unfiltered sample, Figure 7), is different (greater absor-

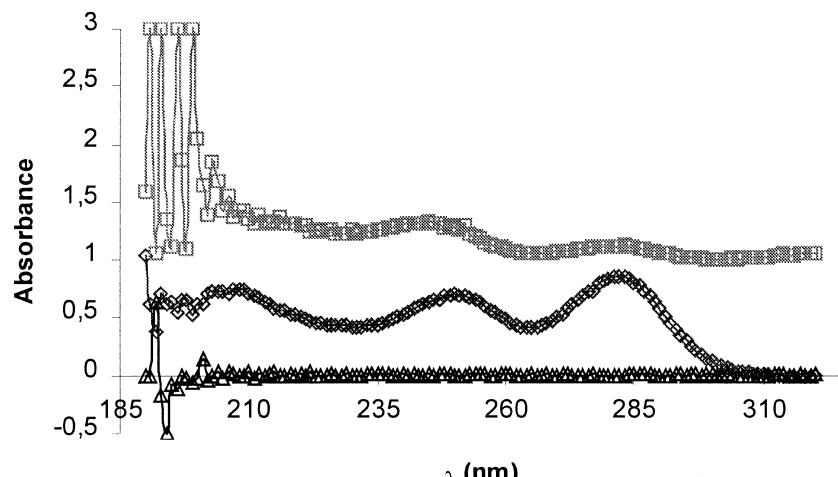

$\lambda(\mathrm{nm})$

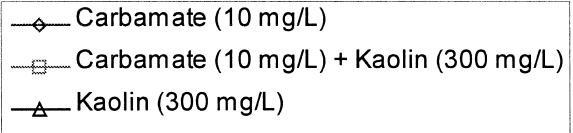

Figure 7-UV absorbency scanning curves of nonfiltrated samples of the carbamate solution, the kaolin suspension, and the kaolin plus carbamate suspension ( $\lambda=$ wavelength). 


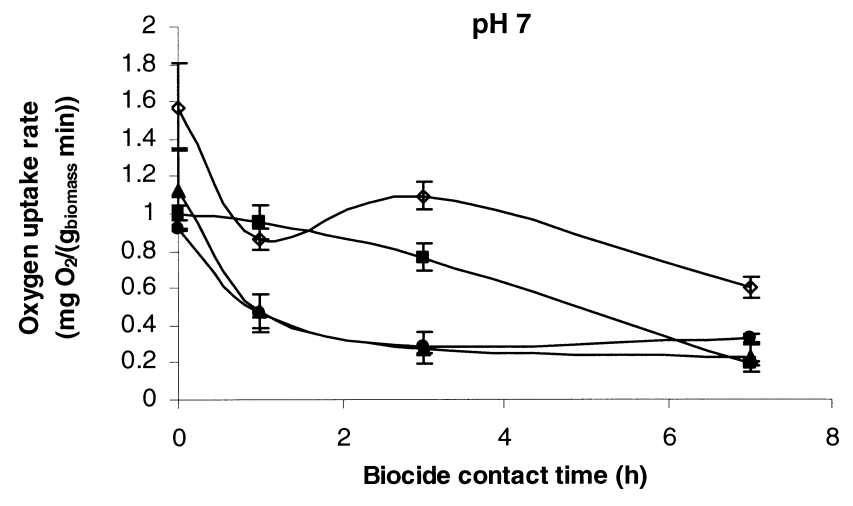

$\multimap 0 \mathrm{mg} / \mathrm{L} \rightarrow-100 \mathrm{mg} / \mathrm{L} \multimap 200 \mathrm{mg} / \mathrm{L} \multimap-300 \mathrm{mg} / \mathrm{L}$

Figure 8-Oxygen uptake rates of suspended cultures of $P$. fluorescens, $\mathrm{pH} 7$ phosphate buffer, without kaolin, when treated with different concentrations of carbamate, as a function of time; the bars display the standard deviation of the mean value.

bencies) from the one obtained when kaolin particles are removed by filtration (Figure 6). Therefore, chemical adsorption of carbamate, instead of simply physical adsorption, seems to occur.

On the other hand, it has been often reported that particleattached bacteria are less sensitive to biocides than the same bacteria in the planktonic state (LeChevallier et al., 1990; Morton et al., 1998; and Nichols, 1989). Therefore, the low biocide efficacy obtained in the present assays could be the result of the conjugation of the chemical adsorption of carbamate onto kaolin particles (Table 1). Furthermore, the low biocide efficacy of the carbamate and kaolin suspensions is a result of its decreased concentration as an active compound (i.e., its availability to bacteria) and the effect of cell adhesion to the particles that may protect them from hostile external conditions.

The previous approaches were illustratively tested with further respirometric experiments carried out at a $\mathrm{pH} 7$ phosphate buffer, with carbamate but without kaolin addition (Figure 8). Table 2 compares the results obtained in these tests to those obtained in the assays with $300 \mathrm{mg} / \mathrm{L}$ of kaolin (the same biocide concentrations were applied in both cases) (Figure 3). The reduction in bacterial activity in the presence of kaolin plus carbamate is considerably less than in the assays without kaolin particles. This means that the presence of kaolin particles in suspended cultures of $P$. fluorescens reduces the efficacy of the carbamate as a biocide.

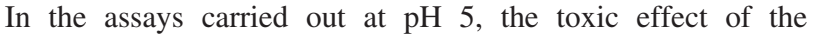
carbamate-based biocide was not, in general, detected. Surprisingly, the respirometric tests at this $\mathrm{pH}$ (Figure 5) show an increase in the activity for carbamate concentrations of 100 and $200 \mathrm{mg} / \mathrm{L}$. Once again, the specific kaolin structure plus the carbamate interaction with the particles (Table 1) may explain this behavior. The larger surface area provided by the "house of cards" configuration seems to have, in this case, a predominate role in bacteria protection and stimulation because the toxic effect of carbamate addition was not evident. Only for the greatest carbamate concentration $(300 \mathrm{mg} / \mathrm{L})$ a reduction in $P$. fluorescens activity is visible, meaning that, in this case, the biocidal effect prevails over the protective role of the kaolin particles.

\section{Conclusions}

The present study showed that the kaolin particles caused a relative stimulation of the respiratory activity of $P$. fluorescens cells at each $\mathrm{pH}$ in buffered suspensions. The increase in bacterial activity was more visible in the tests carried out at $\mathrm{pH} 5$ and 9. These facts proved that mechanisms other than maintenance of the $\mathrm{pH}$ are involved in enhancing respiration. The results also indicated that the presence of the clay reduced the carbamate efficiency as a biocide. Parallel tests demonstrated that kaolin possessed the ability to remove carbamate from the culture media, thus decreasing its availability to bacteria. This removal effect seems to be associated with a chemical adsorption phenomenon resulting in modification of the toxic compound.

The different configurations, depending on the $\mathrm{pH}$, adopted by kaolin aggregates (card house and card pack) may explain some of the results obtained. The kaolin card-house geometry represents a system with an increased surface area in which a more favorable microenvironment to bacteria can be established.

The results, mainly the loss of efficiency of carbamate against $P$. fluorescens suspensions attributable to kaolin particles, suggest that in industrial water systems new and practical implications could arise, because clays (quite frequent in water systems) could interfere with the biocide-dosing program. In such industrial systems, the use of biocides to reduce or eliminate microorganisms, mainly when they are entrapped in a biofilm, is widespread. Therefore, knowledge of the effect of clay particles on the efficacy of these biocides are of primary importance.

Table 2-Reduction in the bacterial activity in the assays performed at pH 7.

\begin{tabular}{|c|c|c|c|c|c|c|}
\hline \multirow{2}{*}{$\begin{array}{l}\text { Biocide } \\
\text { contact time } \\
\text { (h) }\end{array}$} & \multicolumn{6}{|c|}{ Bacterial activity reduction (\%) ${ }^{a}$} \\
\hline & \multicolumn{3}{|c|}{ Without kaolin } & \multicolumn{3}{|c|}{ With $300 \mathrm{mg} / \mathrm{L}$ of kaolin } \\
\hline 0 & 36.3 & 28.2 & 41.8 & 2.1 & 3.1 & 2.7 \\
\hline 7 & 68.3 & 63.3 & 46.0 & 38.0 & 39.3 & 59.1 \\
\hline
\end{tabular}

a The percentage of reduction was calculated based on the control assay, that is, on the respiratory activity of the bacterial suspensions without carbamate. 


\section{Acknowledgments}

Credits. The authors acknowledge the financial support of program PRAXIS (Lisbon, Portugal) through project $n^{\circ} 2 / 2.1 / \mathrm{BIO} /$ $37 / 94$ and grant $n^{\circ}$ BD/3242/94 awarded to Maria Olivia Pereira, and the financial support provided by Instituto de Biotecnologia e Química Fina (IBQF, Braga, Portugal). The authors are also grateful to Dr. Fernanda Proença (Chemical Department, University of Minho, Braga, Portugal) and Rosário Oliveira (Biological Engineering Department, University of Minho) for providing several useful suggestions during the course of this work.

Authors. Maria Olivia Pereira is a Ph.D. student in the Department of Biological Engineering of the University of Minho. Maria João Vieira and Luis F. de Melo are, respectively, Assistant Professor and Full Professor in the department. Correspondence should be addressed to Luis F. Melo, Faculty of Engineering of the University of Porto, Department of Chemical EngineeringLEPAE, 4200-465 Porto, Portugal; e-mail: lmelo@fe.up.pt.

Submitted for publication July 31, 2000; revised manuscript submitted January 23, 2002; accepted for publication February $28,2002$.

The deadline to submit Discussions of this paper is September $15,2002$.

\section{References}

Amin, S.; Jayson, G.G. (1996) Humic Substance Uptake by Hydrotalcites and Pilcs. Water Res., 2, 299.

Burns, R.G. (1975) Factors Affecting Pesticide Loss from Soil. In Soil Biochemistry; E.A. Paul and A.D. McLaren, Eds.; Marcel Dekker: New York; 103.

Burns, R.G. (1989) Microbial and Enzyme Activities in Soil Biofilms. In Structure and Function of Biofilms; W.G. Characklis and P.A. Wilderer, Eds.; Wiley-Interscience: New York: 333.
Castellar, M.R.; Aires-Barros, M.R.; Cabral, J.M.S.; Iborra, J.L. (1998) Effect of Zeolite Addition on Ethanol Production from Glucose by Saccharomyces bayanus. J. Chem. Technol. Biotechnol., 73, 377.

Daniel, W.W. (1987) Biostatistics: A Foundation for Analysis in the Health Sciences; Wiley and Sons: New York.

Huang, C.; Yang, Y-L. (1995) Adsorption Characteristics of Cu(II) on Humus-Kaolin Complexes. Water Res., 11, 2455.

LeChevallier, M.W.; Lowry, C.D.; Lee, R.G. (1990) Disinfecting Biofilms in a Model Distribution System. Research and Technology. J Am. Water Works Assoc., 87.

Michaels, A.; Bolger, J.C. (1962) Settling Rates and Sediments Volumes of Flocculated Kaolin Suspensions. IEC Fundam., 1, 24.

Morton, L.H.G.; Greenway, D.L.A.; Gaylarde, C.C.; Surman, S.B. (1998) Consideration of Some Implications of the Resistance of Biofilms to Biocides. Int. Biodeter. Biodegrad., 41, 247.

Nichols, W.W. (1989) Susceptibility of Biofilms to Toxic Compounds. In Structure and Function of Biofilms; W.G. Characklis and P.A. Wilderer, Eds.; Wiley-Interscience: New York; 321.

Nogueira, R.; Lazarova, V.; Melo, L.F. (1998) Respirometric Tests Applied to the Monitoring of a Nitrifying Biofilm Reactor. In Microbial Ecology of Biofilms: Concepts, Tools, and Applications. Proc Int. Spec. Conf., Illinois.

Srinivasan, R.; Stewart, P.S.; Griebe T.; Chen, C-I.; Xu X. (1995) Biofilm Parameters Influencing Biocide Efficacy. Biotechnol. Bioeng, 46, 553.

Stotzky, G. (1986) Influence of Soil Mineral Colloids on Metabolic Processes, Growth, Adhesion, and Ecology of Microbes and Viruses. In Interactions of Soil Minerals with Natural Organics and Microbes; P.M. Huang, and M. Schnitzer, Eds.; Soil Society of America, Inc.; 305.

Vieira, M. J.; Pacheco, A. P.; Pinho, I. A.; Melo, L. F. (2001) The Effect of Clay Particles On the Activity of Suspended Autotrophic Nitrifying Bacteria and On the Performance of an Air-Lift Reactor. Environ. Technol., 22, 123. 
AQ1 Oliveira et al and Pinheiro et al not listed in Reference section. Please provide.

AQ2 Is conference name complete? Should there a sponsoring association? 